\author{
(online) = ISSN $2285-3642$ \\ ISSN-L = $2285-3642$ \\ Journal of Economic Development, Environment and People \\ Volume 2, Issue 1, 2013 \\ URL: http://jedep.spiruharet.ro \\ e-mail: office jedep@spiruharet.ro
}

\title{
Education of the next generation of managers in context of green economy
}

\author{
Jana Chovancová ${ }^{1}$, Helena Harausová ${ }^{2}$ \\ ${ }^{1}$ University of Prešov in Prešov, Faculty of Management, Department of environmental management, 17. \\ novembra 1, 08001 Prešov \\ ${ }^{2}$ Pavol Jozef Šafárik University in Košice, Faculty of Public Administration, Department of Social Studies, \\ Popradská 66, 04132 Košice
}

\begin{abstract}
This paper deals with the issue of education for sustainable development of the generation of future managers in the context of the green economy. The paper analyses the need for environmental education of graduates in theoretical way who are expected to act as executives and in positions which are defined as Green Enhanced Skills Occupations or shortly Green Jobs and who should be able to apply the tools of environmental protection in a business sector, municipalities or third sector. The essential part of the article presents the partial results of the research, which was focused on finding whether students of economic universities are aware of issue of sustainable development and environmental policy tools, which can help the implementation of green economy in the practice and whether this issue is taught at universities. At the end of the article authors point out the important role of universities in preparing the future managers to work in the green economy.
\end{abstract}

Keywords: Sustainable development, Future managers, Education and training, Environmental policy tools, Green economy, Green Enhanced Skills Occupations

JEL Codes: A20, A23, Q01, Q56 


\author{
(online) = ISSN $2285-3642$ \\ ISSN-L = $2285-3642$ \\ Journal of Economic Development, Environment and People \\ Volume 2, Issue 1, 2013 \\ URL: http://jedep.spiruharet.ro \\ e-mail: office jedep@spiruharet.ro
}

\title{
1. Introduction
}

The issue of sustainable development (SD) is richly developed theoretically and supported for over 20 years, yet the problem still remains i.e. the transfer into practice. The reserves of natural resources are being exploited by tremendous speed. On the other hand, human population, excessive consumption and damage of life supporting ecosystems are growing. In this situation the green economy as a tool of sustainable development is gaining on interest.

In the paper the authors focus on education and training as an essential tool of change. Society of the 21st century expects that its members will be able to understand and solve the integrated problems of humanity (environmental, social, and economical) both in the local and global environment and that they will be equipped for practical application of sustainable development in practical life.

\section{Environmental education and awareness}

The need for environmental education is embedded in many international and national documents. The most important are The Lisbon Strategy (revised in 2005), where the first priority action was "investing more in knowledge and innovation", Europe 2020 - a 10-year strategy which follows the Lisbon Strategy and The European Union Strategy for Sustainable Development (revised in 2009), where education is considered an important instruments in facilitating the transition to a more sustainable production and consumption patterns. Based on these strategies the national documents have been created and implemented within EU member states, e.g. in Slovakia it is "The concept of environmental education at all school levels in the Slovak Republic and the system of lifelong learning " (2006) and its Action Plan - "Action Plan for Education and Training for Sustainable Development in SR" (2006), "National Biodiversity Strategy of Slovakia" (1997), "Action Plan for Sustainable Development of SR in the years 2005 - 2010" (2005), "The UNECE Strategy for education for sustainable Development" (2005), as well as other national and international commitments of the Slovak Republic.

In 2009 the national conference with international participation took place in Slovakia. The conference was organized by the Faculty of Natural Sciences of Matej Bel University in Banska Bystrica. It was already the fifth conference, referred mostly to third and forth national conference focused on issues of environmental education in schools of the Slovak Republic, and on the other hand, it was based on the conclusions and recommendations of meetings of representatives of ministries of environment and education, held in Vilnius in 2005, contained in the UNECE Strategy for education for sustainable development. The outputs of the conference were published in the Proceedings of education for sustainable development ${ }^{1}$. Dozens of contributions were presented at the conference and they were

\footnotetext{
${ }^{1}$ Halašová, M. (ed.) (2009). Výchova a vzdelávanie k trvalo udržatel'nému rozvoju. Zborník príspevkov a závery z 5. národnej konferencie s medzinárodnou účastou konanej 21.-22. januára 2009 v Banskej Bystrici, Banská Bystrica 2009, ISBN 978-80-8083-876-8
} 


\author{
(online) = ISSN $2285-3642$ \\ ISSN-L $=2285-3642$ \\ Journal of Economic Development, Environment and People \\ Volume 2, Issue 1, 2013 \\ URL: http://jedep.spiruharet.ro \\ e-mail: office jedep@spiruharet.ro
}

divided into four sections. The papers were focused on the environmental education as well as other current topics of environmental protection and sustainable development.

Rands (2009) deals with this issue as well and refers to the principle of personal responsibility, through which individuals contribute to sustainable development. Managers as well as the future managers can be seen as a group of individuals who have a lot of power and responsibilities. Therefore, environmental education and education for sustainable development of managers can be seen as key to implementing the principles of sustainable development into practice.

Two special issues of the magazines (1) The Journal of Teaching in International Business ${ }^{2}$ and (2) Journal of Management Education ${ }^{3}$ dealt with the topic of environmental education of managers, which included nine articles. The articles opened various topics and proposed solutions for faculties with the focus on management and economy and how they could include the problems of environmental protection to the curriculum of future managers and the questions of environmental education of managers. The magazine contained eight articles which provided concepts, pedagogical approaches, case studies, seminars curriculum, practical lessons and activities focused on the integration of environmental protection into existing courses or on creation of special courses on this topic.

Authors of the above mentioned articles unite in the opinion, that environmental education of managers should support the awareness, understanding and interest, which motivate the students to environmental activities and environmentally sustainable behaviour in their personal, social and professional life.

It is necessary to rethink the changing meaning of the term "sustainable development". Therefore, development of sustainable society must be understood as continual process of learning, researching the problems and perplexity, where correct answers and solutions can be changed with the growth of our experience.

Halašová, M. (2009) states, that educational goal of sustainable development should include broadening the knowledge, development of special behaviour, intellect, forming of life attitudes and values. Education toward sustainable developments is still being formed as a broad and complex conception, which includes interconnected ecological, economical and social questions. It broadens the concept of environmental education, which includes an increasing range of questions regarding development, various forms of education about the questions of development and other topic-focused forms of education. Therefore, environmental education should be re-made and more branches within the range of complex approach to the education to sustainable development should be added.

\footnotetext{
${ }^{2}$ Mintu, A. T., Lozada, H. R., Polonsky, M. J. (1993). Environmental consciousness and the business curricula: Some thoughts. Journal of Teaching in International Business, 5, XV-XVIII

3 Egri, C.P. , Rogers, K. S. (2003). Teaching about the natural environment in management education: New directions and approaches. Journal of Management Education
} 


\author{
(online) $=$ ISSN $2285-3642$ \\ ISSN-L = $2285-3642$ \\ Journal of Economic Development, Environment and People \\ Volume 2, Issue 1, 2013 \\ URL: http://jedep.spiruharet.ro \\ e-mail: office jedep@spiruharet.ro
}

Inclusion of ethical dimension, questions of equality, solidarity, reciprocal dependence among generations, as well as reciprocal relations among people and nature and among the rich and the poor, has an important meaning by building environmental awareness and education of future managers toward sustainable development.

On the present the requirements for qualification of graduates of all types of schools are changing. Issues of so called Green jobs are getting to the fore. Bellan (2010) states that the quantitative changes in the labour market are accompanied with qualitative changes, in particular changes related to qualification requirements. Greening of economy pursues three basic types of the qualification effects: on increase in demand for jobs with the same qualifications, job changes in given scale and level of qualifications needed, create new jobs with entirely new qualification requirements.

In connection with these changes in the labor market and the emergence of green jobs universities can play an important role in education of future managers and preparing them for new conditions in new green economy. Comprehensive education of the topic of sustainable development and tools of environmental policy will be essential for bringing the green economy to life.

\title{
3. Environmental policy tools
}

Development of opinions for solution of the problems of sustainable development was reflected in the EU policy, where a broad spectrum of tools was established, which can be used by organizations and managers to improve their environmental performance. Chovancová (2012) states the most known and widely used tools: Environmental management systems (EMS) according to ISO 14001, Eco-management and audit scheme (EMAS), cleaner production, corporate social responsibility etc. Their implementation in the corporate (and public) sphere is voluntary. Majerník, Chovancová, Hodolič (2009) state, that these tools are aimed for organizations, which want to valorise and improve their environmental behaviour, minimize negative influence on the community and environment, where they carry out their activities. Implementation of these tools requires financial investments and also support from the management and all employees. On the other hand, for the organization, these investments can bring a better position on the market and improve relations with other parties and other important added values. Bellan (2010) indicates that in the context of the green economy the question of how to set the environmental policies and tools of environment protection so that besides ensuring the transition to a greener and more sustainable economy they would also facilitate the economic recovery and employment growth is getting into the spotlight.

\section{Research}

The goal of the research was to find out, how much the teaching about the topic of sustainable development correlates with the amount of information provided for the Slovak, Polish and Hungarian students - the future managers. Partial goal of the research was to investigate whether the Slovak, Polish and Hungarian students have the need to educate and develop themselves in this field. These are the 


\author{
(online) = ISSN $2285-3642$ \\ ISSN-L = $2285-3642$ \\ Journal of Economic Development, Environment and People \\ Volume 2, Issue 1, 2013 \\ URL: http://jedep.spiruharet.ro \\ e-mail: office jedep@spiruharet.ro
}

basic data which show us the correlation between teaching the topic of sustainable development and the students' knowledge.

\title{
4.1. The research methodology
}

A questionnaire was used for acquisition of basic data. Besides other things, it included the questions about the knowledge of students about the environmental policy tools, which closely relate to sustainable development and green economy, and a question, if, as future managers, they consider education in the field of environmental protection and sustainability necessary. The closed questions were used in the questionnaire and the students could choose from five options within the Likert scale. The research was carried out in the first half of 2012. Two research questions were formulated within the research:

1. Is there a difference between the amount of knowledge related to the environmental policy tools among Slovak, Polish and Hungarian students?

2. Is there a difference in opinions on environmental education of future managers among Slovak, Polish and Hungarian students?

\subsection{The research sample}

The research sample consisted of 173 students from Slovakia, 100 students from Poland and 47 students from Hungary. All of them were students of economics and/or management. Postgraduate students were addressed. The average age of students was 23 years. It was assumed that these students might get in touch with the topic of green economy, sustainability or environmental protection during their graduate studies or it could be the topic of their diploma thesis. The students were not addressed statistically at random. An important issue when addressing the students was the opportunity of delivering the questionnaire personally, in order to obtain high questionnaire return and assure the most relevant results.

\subsection{Results and interpretation of data}

At first, the knowledge about specific environmental policy tools was evaluated. It included following tools: system of environmental management according to ISO 14001, EU regulation about ecomanagement and audit scheme EMAS, Life Cycle Assessment - LCA, Corporate Social Responsibility CSR, Environmental Performance Evaluation and Eco labelling. In order to obtain results, following steps were taken: points were assigned for every possible answer within the Likert scale according to their importance. The importance of answers were set by the authors as follows: know about it -5 points, more or less know about it -4 pts, maybe -3 pts, more or less do not know -2 pts, do not know -1 pt. 


\author{
(online) $=$ ISSN $2285-3642$ \\ ISSN-L = $2285-3642$ \\ Journal of Economic Development, Environment and People \\ Volume 2, Issue 1, 2013 \\ URL: http://jedep.spiruharet.ro \\ e-mail: office jedep@spiruharet.ro
}

As the next step, sum of particular multiplications was made and the resulting sum was divided by 5 . By this calculation was obtained the average coefficient of frequency of answer appearance. The highest obtained value of coefficient represents the highest level of knowledge; the lowest value of coefficient represents the lowest level about the particular environmental policy tool. Particularly obtained results were arranged into a table which shows, which environmental policy tool is mostly known among students Radar graph was used for graphical presentation for easy visual arrangement of data.

\begin{tabular}{|l|c|c|c|}
\hline Instrument of environmental protection & \multicolumn{3}{|c|}{ Coefficient of frequency } \\
\hline & Slovaks & Poles & Hungarians \\
\hline Environmental management system according to ISO 14001 & 2,98 & 3,26 & 2,04 \\
\hline Regulation (EC) on Eco-management and audit scheme - EMAS & 2,15 & 2,89 & 1,38 \\
\hline Life cycle assessment - LCA & 2,17 & 3,11 & 2,12 \\
\hline Corporate social responsibility (CSR) & 4,03 & 3,56 & 2,83 \\
\hline Environmental performance evaluation (EPE) & 2,93 & 3,90 & 3,21 \\
\hline Ecolabelling & 3,32 & 4,06 & 2,63 \\
\hline
\end{tabular}

Table 1: Overview of the knowledge about environmental policy tools

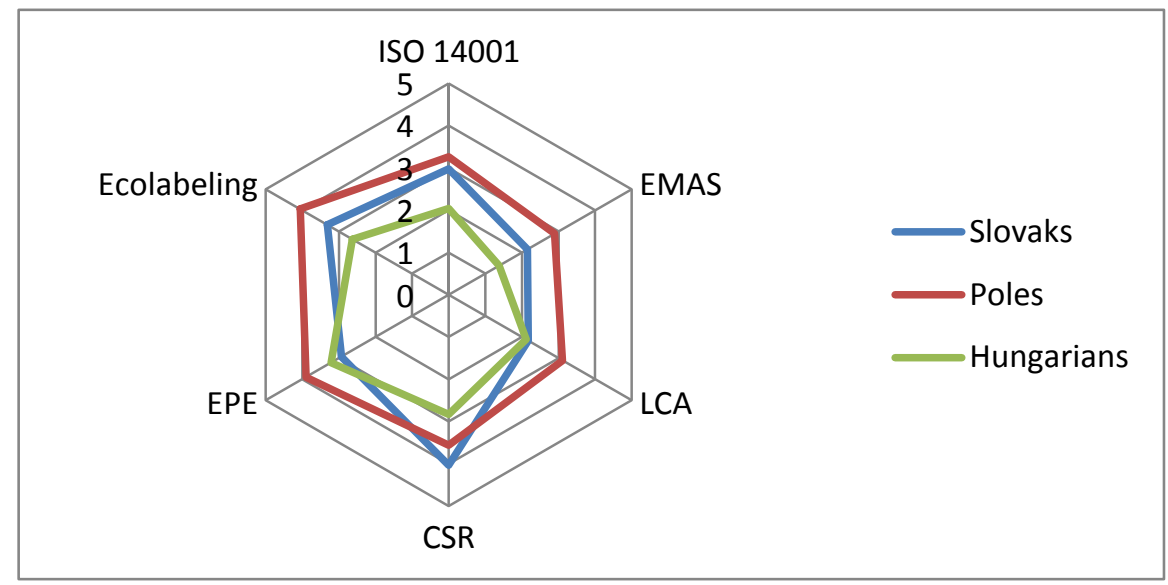

Fig. 1: Knowledge about environmental policy tools

As it can be seen from the presented results, the Slovak students have greatest knowledge about the corporate social responsibility. This topic is present in the curriculum of the subject "international management", which it taught at business and management oriented universities. The issue is not only lectured but also practically trained by problem tasks and case studies. Based on this assumption, the authors expected that students will have good knowledge about this instrument in particular and the expectation was confirmed. Polish students have the widest knowledge about Ecolabelling. Hungarian 


\author{
(online) = ISSN $2285-3642$ \\ ISSN-L = $2285-3642$ \\ Journal of Economic Development, Environment and People \\ Volume 2, Issue 1, 2013 \\ URL: $\underline{\text { http://jedep.spiruharet.ro }}$ \\ e-mail: office jedep@spiruharet.ro
}

students are most aware of Environmental Performance Evaluation. Ecolabelling reached the second place among Slovak students. The assumption was that those students, who care when buying environmentally friendly products, will at least partially know about this issue. This assumption was confirmed. The same can be assumed about Polish and Hungarian students, where Ecolabelling reached high score, too. Recently, in press and other media, environmental management system according to ISO 14001 is often mentioned, related to its implementation into praxis of some organisations, and therefore it was assumed, that students have already heard about the system, but they do not know what it is about. The value of coefficient reached 2,98 among Slovak students, which confirms the correct assumption of the authors. Among Polish students the coefficient was about 0,28 higher, which means that they have more knowledge about this tool than Slovak students. Among Hungarian students coefficient reached 2,04; which in average is less than 1,08 in comparison to Slovak and Polish students. This shows that Hungarian students do not have enough knowledge about this tool. Regulation (EC) on Eco-management and audit scheme - EMAS and Life cycle assessment - LCA is not taught in most Slovak schools at all and if it is, then only on a minimal level, therefore, it was assumed, that Slovak students will have a minimal knowledge about these tools. The assumption was confirmed - coefficients reached the lowest values.

According to calculated coefficients Polish students have more knowledge about these tools than Slovak students. Hungarian students reached the lowest values of coefficients. Polish students have more knowledge about issues of environmental performance evaluation than Hungarian and Slovak students. Based on the results evaluation the first research question can be answered. There are the differences in the amount of knowledge about environmental policy tools among Slovak, Polish and Hungarian students.

Table 2: The organization of data using descriptive statistics

\begin{tabular}{|l|l|l|l|l|l|}
\hline & N & Minimum & Maximum & Mean & Std. Deviation \\
\hline Slovak & 6 & 2 & 4 & 2,93 & 0,714 \\
\hline Poland & 6 & 3 & 4 & 3,46 & 0,458 \\
\hline Hungarien & 6 & 1 & 3 & 2,37 & 0,654 \\
\hline Valid N (listwise) & & & & & \\
\hline
\end{tabular}

After assessing the overall average coefficients, the Polish students reached the highest score 3.46. Slovak students reached 2.93 and Hungarian students 2.37. Based on these data, it can be concluded that Polish students have the greatest knowledge about environmental policy tools, followed by Slovaks and Hungarian students have the smallest amount of knowledge about these tools. 


\author{
(online) = ISSN $2285-3642$ \\ ISSN-L = $2285-3642$ \\ Journal of Economic Development, Environment and People \\ Volume 2, Issue 1, 2013 \\ URL: $\underline{\text { http://jedep.spiruharet.ro }}$ \\ e-mail: office jedep@spiruharet.ro
}

The answer to the second research question was sought by the methods of descriptive statistics. The following statement of Slovak, Polish and Hungarian students was rated in this research question.

Statement: "As a manager I think it is necessary to be educated in the field of environmental protection". For the evaluation these methods of descriptive statistics were used: frequency of responses and due to unequal number of Slovak, Polish and Hungarian students the percentage of answers; to allow comparisons of responses obtained. Obtained data are presented in a tabular form as well as graphically using a bar chart.

Table 3: Frequency of answers and their expression in percent.

\begin{tabular}{|l|c|c|c|c|c|c|}
\hline Possible answers & \multicolumn{3}{|c|}{ Frequency } & \multicolumn{3}{c|}{ \% expression } \\
\hline & Slovaks & Poles & Hungarians & Slovaks & Poles & Hungarians \\
\hline Yes & 83 & 51 & 25 & 47,98 & 51,00 & 53,19 \\
\hline Rather yes & 75 & 46 & 15 & 43,36 & 46,00 & 31,91 \\
\hline Maybe & 13 & 2 & 6 & 7,51 & 2,00 & 12,76 \\
\hline Rather no & 1 & 1 & 0 & 0,05 & 1,00 & 0,00 \\
\hline No & 0 & 0 & 1 & 0,00 & 0,00 & 0,02 \\
\hline
\end{tabular}

Table 4: The organization of data using descriptive statistics

\begin{tabular}{|l|l|l|l|l|l|}
\hline & N & Minimum & Maximum & Mean & Std. Deviation \\
\hline Slovak & 5 & 0 & 48 & 19,78 & 23,887 \\
\hline Polish & 5 & 0 & 51 & 20,00 & 26,086 \\
\hline Hungarians & 5 & 0 & 53 & 19,61 & 22,869 \\
\hline Valid N (listwise) & 5 & & & & \\
\hline
\end{tabular}

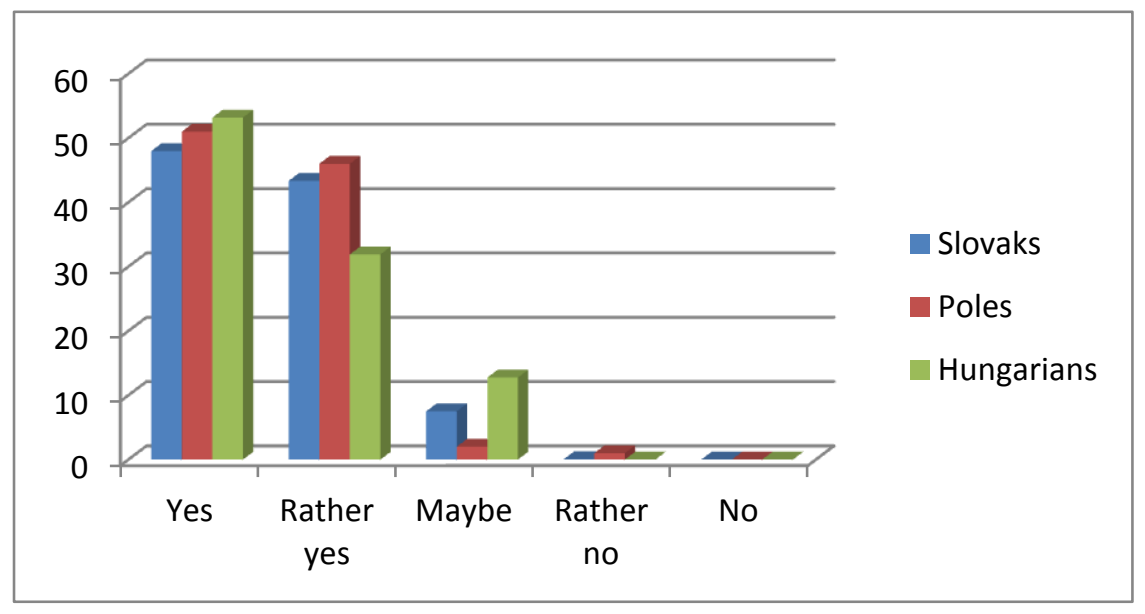

Fig. 2: Opinions of students on environmental education. 


\author{
(online) $=$ ISSN $2285-3642$ \\ ISSN-L = $2285-3642$ \\ Journal of Economic Development, Environment and People \\ Volume 2, Issue 1, 2013 \\ URL: http://jedep.spiruharet.ro \\ e-mail: office jedep@spiruharet.ro
}

As can be seen from Table 4 - Mean value, the most aware of a need of environmental education are Polish students, followed by Slovak students and the least aware are Hungarian students. Based on the evaluation of responses it can be concluded that the Slovak, Polish and Hungarian students recognise the importance of protecting the environment and the importance of acquiring knowledge and skills through their university study. The proof of that is also the fact that no Slovak and Polish student stated $\mathrm{s} /$ he should not be educated in this area (just one Hungarian student said that he does not need to be educated in this area). The graph shows that students clearly considered it as necessary to be educated in the field of environmental protection and sustainable development. From a statistical evaluation the answer to the second research question was revealed. There is a minimal difference in the views of Polish, Slovak and Hungarian students to educate managers in the field of environmental protection and sustainable development. This discovery also justifies the need for education about environmental protection and sustainable development at universities in Slovakia, Poland and Hungary.

\title{
5. Discussion
}

The results of the research showed, that it is very important to implement the issues of environmental protection and sustainable development into the curriculum of suitable subjects; with no exception of business schools and universities. If the topic is presented by an adequate, creative and motivating teaching methods (discussions, case studies, practical examples etc.), they will be able to support awareness, understanding and interest of students for environmental protection in the way as it is stated by the authors already mentioned above. The authors unite in the idea that environmental education of managers should support awareness, understanding and interest, which motivate students to environmental activities and environmentally sustainable behaviour in their personal, social and professional life. The acquired knowledge and skills in this area will enable them to more easily find a job in the labour market in the context of greening the economy. Even though, in the case of future managers, it may not necessarily be the direct employment in so-called green jobs, there may be an indirect employment in the green economy. Future managers will be able to implement projects that will apply the principle of $3 \mathrm{P}$ or Tripple Bottom Line in the management of the company, which can contribute to the realisation of sustainable development and green economy.

Several authors suggest that universities have an important position as the core of the knowledge base, acting as key elements of innovation system, supporting science-based innovation of regional growth (Huggings \& Kitagawa, 2009; Zsibók \& Gál, 2012). Universities therefore may play a key role in building the green economy that would respond to the social demand and to prepare future graduates for the green enhanced skills occupations. Universities have in this area a number of options that could be used. First is the transfer of knowledge and know-how on environmental protection and sustainable development. This information should, however, encourage personal responsibility of managers, through which, as stated in Rands (2009) individuals contribute to sustainable development, as well as 


\author{
(online) = ISSN $2285-3642$ \\ ISSN-L = $2285-3642$ \\ Journal of Economic Development, Environment and People \\ Volume 2, Issue 1, 2013 \\ URL: http://jedep.spiruharet.ro \\ e-mail: office jedep@spiruharet.ro
}

motivation, which in Kravčáková (2007) plays an important role of managers in implementing their activities. Motivation is also important for future managers, who will be employed in green jobs and who would want to apply different tools in environmental business practice. Universities can serve and "teach" also by their own example. Environmental educator David Orr (1992) suggests that a key element in the development of ecological literacy is the opportunity for students to engage in hands-on learning about environmental problems. The specific activities of the universities can demonstrate their own commitment to environmental protection. They also may become a place where students can directly meet, try and participate in various environmental activities. For this purpose numerous universities have coalesced in the "campus sustainability" or "greening the campus" movement, as for example Green campus, Campus Climate Challenge, Campus Ecology etc.

\title{
6. Conclusion
}

Education to sustainable development requires redirecting from providing the knowledge to a discussion about problems and looking for possible solutions. Therefore, education should keep the traditional focus on teaching particular subjects together with possibilities for multilateral and interdisciplinar exploration of real life situations. It should influence the structure of teaching programs and methods, what requires the change in pedagogues - from exclusive transporters, and the change in students - from exclusive recipients, so that both groups build one team.

There are many possibilities for using education towards sustainable development in individual consciousness, but their realisation will require fundamental changes in the approach to education, as well as in universities with focus on management and economy.

\section{Acknowledgements}

Our colleagues on Polish, Hungarian and Slovak universities, namely Marta Starostka Patyk, Alžbeta Suhányiová and Milan Majerník are gratefully acknowledged for helping with distribution of questionnaires and for providing feedback and insightful suggestions.

\section{References}

[1] 2009 Review of the European Union Strategy for Sustainable Development. On line 6.2.2013 <http://eur-lex.europa.eu/LexUriServ/LexUriServ.do?uri=COM:2009:0400:FIN:EN:HTML>

[2] Azapagic, A., Perdan, S., Clift, R. (2004) Sustainable development in practice: Case studies for Engineers and Scientists. John Wiley \& Sons, Ltd. ISBN: 0-470-85609-2

[3] Bellan, P. (2010). Zelené pracovné miesta $v$ kontexte trhu práce SR. On line 22.1. 2013 <www.sspr.gov.sk/IVPR/images/IVPR/vyskum/2010/Bellan/VU-Bellan.pdf >

[4] Egri, C.P. , Rogers, K. S. (2003). Teaching about the natural environment in management education: New directions and approaches. Journal of Management Education

Europe 2020 - A European strategy for smart, sustainable and inclusive growth. On line 6.2.2013

<http://ec.europa.eu/commission 2010-2014/president/news/documents/pdf/20100303 1 en.pdf> 


\author{
(online) = ISSN $2285-3642$ \\ ISSN-L = $2285-3642$ \\ Journal of Economic Development, Environment and People \\ Volume 2, Issue 1, 2013 \\ URL: $\underline{\text { http://jedep.spiruharet.ro }}$ \\ e-mail: office jedep@spiruharet.ro
}

[5] Gál, Z., Zsibók, Z. (2012) Engagement of mid-range universities: Adopting European models and best practices in Hungary. AUDEM: The International Journal of Higher Education and Democracy 2:(1) pp. 94-120.

[6] Halašová, M. (ed.) (2009). Výchova a vzdelávanie k trvalo udržatel'nému rozvoju. Zborník príspevkov a závery z 5. národnej konferencie s medzinárodnou účast'ou konanej 21.-22. januára 2009 v Banskej Bystrici, Banská Bystrica 2009, ISBN 978-80-8083-876-8

[7] Huggins, R., Kitagawa, F. (2009). Devolution and knowledge transfer from universities: Perspectives from Scotland and Wales. Discussion Paper: Impact of Higher Education Institutions on Regional Economies Initiative. Cardiff: University of Wales Institute

[8] Huttmanová, E., Adamišin, P., Hronec, O. (2009). Mozliwości środowiskowego ksztalcenia i wychowania w procesie edukacyjnym w Slowacji. In: Edukacja biologiszna i środowiskowa. nr. 4 (32) 2009. p. 5 - 10. ISSN 1643-8779.

[9] Chovancová, J. (2012). Systémy environmentálneho manažérstva, Prešov: Prešovská univerzita v Prešove, 2011, $98 \quad$ s. $\quad$ ISBN:978-80-555-0485-8, $\quad$ On $\quad$ line http://www.pulib.sk/elpub/FM/Chovancova2/index.html>

[10] Korálová, K. Paulíková, A. 2008. Environmentálna výchova na vysokých školách ako súčast' udržatel'ného rozvoja Slovenska. In: RUSKO, M. - BALOG, K. [Eds.] 2008: Manažérstvo životného prostredia 2008. - Zborník z konferencie so zahraničnou účastou konanej 5.-6.12. 2008; Bojnice. Žilina: Strix et VeV, Prvé vydanie. ISBN 978-80-89281-34-3.

[11] Krasny, E. M., Lundholm, C., Plummer, R. (2010). Environmental ecudation, resilience, and learning: reflection and moving forward. Environmental Education Research, Vol. 16. Nos. 5-6, October 2010, 665-672, ISSN $1350-$ 5622

[12] Kravčáková, G.: Metódy manažmentu pracovnej motivácie. In: Zborník vedeckých prác katedry ekonómie a ekonomiky ANNO 2007. - Prešov : Prešovská univerzita v Prešove, 2007. - ISBN 9788080686574. - S. 86-102.

$\begin{array}{llllll}\text { [13] Lisbon Strategy for Growth } & \text { Ond Jobs. } & \text { One } & \end{array}$ <http://ec.europa.eu/archives/growthandjobs 2009/>

[14] Majerník, M., Chovancová, J., Juríková, J. (2008). Implementácia úloh Akčného plánu výchovy a vzdelávania k TUR do vedecko-výskumných a pedagogických aktivít Katedry environmentalistiky a riadenia procesov, TU Košice - identifikácia bariér a príležitostí. Výchova a vzdelávanie $\mathrm{k}$ trvalo udržatel'nému rozvoju na slovenských vysokých školách : zborník príspevkov zo seminára. Bratislava: Univerzita Komenského v Bratislave, Prírodovedecká fakulta, p. 50-55, ISBN:978-80-223-2581-3

[15] Majerník, M., Chovancová, J., Hodolič, J. (2009). Environmentálne manažérske systémy. Skalica : Stredoeurópska vysoká škola v Skalici, 2009, 160 s. ISBN:978-80-89391-05-9

[16] Majerník, M., Bosák, M., Chovancová, J. (2006) Educational concept of eco-management and audit scheme (EMAS) at Slovakian universities. Globalne i regionalne problemy ochrony srodowiska : praca zbiorowa. Gdansk : Wydawnictwo Gdanskiej wyzszej szkoly administracji, 2006. p. 225-236 ISBN:83-89762-06-4

[17] Mintu, A. T., Lozada, H. R., Polonsky, M. J. (1993). Environmental consciousness and the business curricula: Some thoughts. Journal of Teaching in International Business, 5, XV-XVIII 


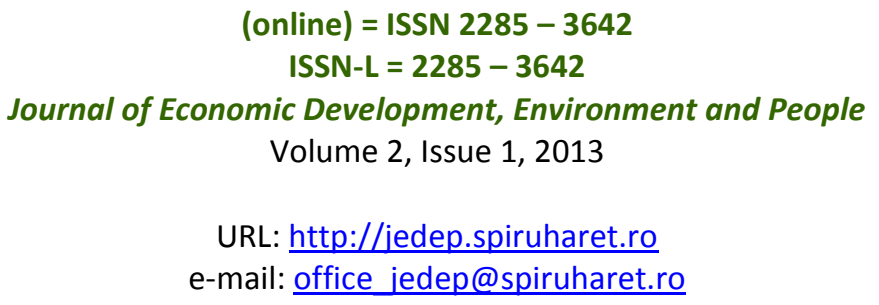

[18] Orr, D. (1992) Ecological literacy: Education and the transition to a postmodern world. Albany: State University of New York Press

[19] Rands, G.P. (2009). A principle-Attribute matrix for Environmentally Sustainable Management Education and Its Application. The case for Change-Oriented Service-Learning Projects. Journal of Management Education, Vol. 33, Mumber 3, June 2009, 296-322, ISSN 1052-5629 